\title{
Chamorro Standard Time
}

National Cancer Institute

\section{Source}

National Cancer Institute. Chamorro Standard Time. NCI Thesaurus. Code C116271.

Local standard time, based at the 150th meridian east of the Greenwich Observatory, established as ten hours ahead of Coordinated Universal T ime. 